\title{
Faktor Yang Mempengaruhi Kejadian Stroke di Rumah Sakit Umum Daerah Provinsi Kepulauan Riau
}

\author{
Romalina $^{1}$, Jusuf Kristianto ${ }^{2}$, Yunita ${ }^{3}$ \\ ${ }^{1,3}$ Prodi DIII Keperawatan;Poltekkes Kemenkes Tanjungpinang \\ ${ }^{2}$ Prodi DIII Keperawatan Gigi, Poltekkes Jakarta I. \\ email : $\underline{\text { romlin17@gmail.com }}$
}

\author{
Submitted: 22-10-2019, Revised: 23-10-2019, 11-11-2019, 5-12-2019 Accepted: 05-12-2019 \\ DOI: https://doi.org/10.36082/qjk.v13i2.84
}

\begin{abstract}
Abstrak
Stroke menempati urutan pertama sebagai penyebab kematian Rumah Sakit di Indonesia. Berdasarkan Riskesdas (2013) bahwa stroke tidak lagi menyerang masyarakat kota yang berkecukupan tetapi masyarakat dengan sosial ekonomi rendah. Mengacu Widyakarya Nasional Pangan dan Gizi ke X (2012) bahwa angka kecukupan energi masih kurang dan sebaliknya untuk konsumsi protein sudah melebihi dari angka yang dianjurkan. Berdasarkan data dari rekam medis di RSUD Provinsi Kepulauan Riau terdapat angka kejadian stroke sebanyak 100 kasus pada tahun 2014. 141 kasus pada tahun 2015, 337 kasus pada tahun 2016 dan 141 kasus pada periode Januari sampai dengan Juni 2017. Tujuan penelitian ini untuk melihat factorfaktor yang mempengaruhi kejadian stroke di RSUD Provinsi Kepulauan Riau. Penelitian deskriptif dengan desain krosseksional dengan jumlah sampel 257 responden melalui teknik simple random sampling. Analisa data multivariate menggunakan regresi logistic dengan metode backward. Hasil penelitian menunjukkan bahwa tidak terdapat hubungan antara pendidikan dengan kejadian stroke $(p=0,249)$, tidak terdapat hubungan antara riwayat penyakit dengan kejadian stroke $(\mathrm{p}=0,394)$, terdapat hubungan kadar kolesterol darah dengan kejadian stroke $(p=0,005)$, tidak terdapat hubungan antara status pernikahan dengan kejadian stroke $(p=0,614)$, tidak terdapat hubungan antara pekerjaan dengan kejadian stroke $(\mathrm{p}=0,546)$, tidak terdapat hubungan usia dengan dengan kejadian stroke $(p=0,138)$, tidak terdapat hubungan antara jenis kelamin dengan kejadian stroke $(\mathrm{p}=0,457)$. Faktor yang berpengaruh terhadap kejadian stroke adalah usia $(\mathrm{OR}=2,625)$ dan kadar kolesterol darah $(\mathrm{OR}=0,047)$.
\end{abstract}

Kata kunci : faktor-faktor; kejadian; stroke

\footnotetext{
Abstract

Stroke is the first cause of death in Indonesian hospital. Toward by Riskesdas (2013) stroke not even attack the citizen but also low-end economy social status. Toward by Widyakarya Nasional Pangan dan Gizi ke X (2012) aquracy rate still less and the protein consumtion already pass the suggest value. Toward the data from RSUD Kepulauan Riau Province's
}

Medical Record there are the incidence rate of stroke is 100 cases in 2014. 141 cases in 2015, 337 cases in 2016 and 141 cases in Januari until june 2017. The aim of this research is to see some factors that influence the stroke case in RSUD Kepulauan Riau Province. Descriptive research with crossectional design with total sample are 257 respondens bye simple random sampling technique. Multivariate data analysis use logistic regretion with backward metode. The result show that there is no relation between education and stroke case $(p=0249)$, there is no relation between disease history with stroke case $(p=0,394)$, there is a relation between blood cholesterol with stroke case $(p=0,005)$, there is no relation between merried status with stroke case $(p=0,614)$, there is no relation between job with stroke case $(p=0,546)$, there is no relation between age with stroke case $(p=0,138)$, there is no relation gender with stroke case $(p=0,457)$. The influence factor toward stroke case is age $(O R=2,625$ and blood cholesterol $(O R=0,047)$.

Key word : factors, Incidence;stroke

\section{Pendahuluan}

Menurut American Heart Association (AHA) bahwa Stroke adalah penyakit yang berhubungan dengan pembuluh darah arteri yang menuju dan otak. . Gejala awal stroke sulit di kenali karena dapat menyerang siapapun terutama penderita penyakit-penyakit kronis seperti tekanan darah tinggi (hipertensi), kencing manis (diabetes mellitus, jantung, dan lain-lain). Serangan stroke selalu datang mendadak, tanpa tanda-tanda pasti. Komplikasi fatal yaitu kelumpuhan total, atau bahkan mengantar penderita pada kematian (Muttaqin, 2008).

Menurut Ratna (2011) dari hasil penelitiannya bahwa stroke bukan hanya menyerang usia tua tetapi juga menyerang usia muda yang masih produktif. Menurut Sitorus dkk., 2008 dalam Retno tahun 2014 bahwa penyebab utama stroke pada usia yang produktif adalah stress, penyalahgunaan narkoba, alkohol, faktor keturunan, dan gaya hidup yang tidak 
sehat. Penyebab serangan stroke lainnya adalah makanan dengan kadar kolesterol jahat Low Density Lipoprotein (LDL) yang sangat tinggi. Kolesterol jahat ini banyak terdapat pada makanan cepat saji. Selain itu, penyebab terjadinya serangan stroke lainnya adalah kebiasaan malas berolahraga dan bergerak, banyak minum alkohol, merokok, penggunaan narkotika dan zat adiktif, waktu istirahat yang sangat kurang, diet, serta stress yang berkepanjangan. Stress yang diakibatkan oleh beban pikiran yang berat seperti misalnya hubungan social ataupun masalah pendidikan juga turut semakin memicu serangan stroke.

Hal lain yang dapat mempengaruhi adalah pola konsumsi masyarakat. Mengacu pada hasil Widyakarya Nasional Pangan dan Gizi (WNPG) ke X (2012) bahwa Angka Kecukupan Energi (AKE) dan Angka Kecukupan Protein (AKP) untuk rata-rata penduduk Indonesia, masingmasing 2200 Kalori/kapita/hari dan 57 gram/kapita/hari. Maka tingkat konsumsi energi masyarakat Indonesia masih kurang, sebaliknya untuk konsumsi protein sudah melebihi dari angka yang dianjurkan.

Berdasarkan data badan pusat statistik (BPS) Provinsi Kepulauan Riau tahun 2014 bahwa total pengeluaran untuk makanan tahun $2013(45,76 \%)$ dan tahun $2014 \quad(45,21 \%)$ sedangkan untuk konsumsi non makanan tahun 2013 (54,24\%) dan tahun 2014 (54,79\%). Secara keseluruhan nilai rupiah yang dikeluarkan untuk konsumsi pangan masyarakat Provinsi Kepulauan Riau masih didominasi oleh kelompok makanan dan minuman jadi tahun $2013(13,23 \%)$ dan tahun 2014 (12,11\%) diikuti oleh ikan/udang/cumi/kerang tahun 2013 $(5,49 \%)$ dan tahun 2014 (5,98\%). Kelompok komoditi berikutnya yang banyak menyerap pendapatan masyarakat adalah tembakau dan sirih tahun $2013(5,17 \%)$ dan tahun 2014 $(5,12 \%)$.

Penelitian ini bertujuan untuk mengetahui faktor-faktor yang mempengaruhi jenis stroke di RSUD Provinsi Kepulauan Riau Tanjungpinang. Manfaat dari penelitian ini adalah memberikan kontribusi dalam memperbaiki discharge planning lebih spesifik untuk mencegah stroke berulang pada pasien di Rumah sakit. Selain itu penelitian ini juga menjadi faktor motivasi dalam memberikan edukasi tentang faktor resiko stroke kepada masyarakat dilingkungan RS melalui pemanfaatan tekhnologi informasi (televise internal RS atau Web RS).
Penelitian ini merupakan penelitian deskristif dengan desain cross seksional. Dilakukan pencatatan data dari rekam medis pasien meliputi : usia, jenis kelamin, kadar kolesterol darah, riwayat penyakit, pendidikan, pekerjaan, status pernikahan. Dalam penelitian ini, peneliti mengamati faktor-faktor yang mempengaruhi jenis stroke di RSUD Provinsi Kepulauan Riau tahun 2017.

\section{Hasil}

\subsection{Analisis Univariat}

Table 1.1 Karakteristik responden berdasarkan variabel independen dan dependen

\begin{tabular}{llcc}
\hline & & $\begin{array}{c}\text { Jumlah } \\
\text { subjek }(\mathrm{n})\end{array}$ & $\begin{array}{c}\text { Prosentase } \\
(\%)\end{array}$ \\
\hline Jenis kelamin & Perempuan & 130 & 50,6 \\
& Laki -laki & 127 & 49,4 \\
Usia & Tidak Produktif & 89 & 34,6 \\
produktif & 168 & 65,4 \\
& Pendidikan & & \\
& rendah & 117 & 45,5 \\
& Pendidikan & 140 & 54,5 \\
Pekerjaan & tinggi & & \\
& Tidak Bekerja & 92 & 35,8 \\
Status & Bekerja & 165 & 64,2 \\
pernikahan & Tidak Menikah & 43 & 16,7 \\
Kadar & Menikah & 214 & 83,3 \\
kolesterol & Tidak Normal & 214 & 83,3 \\
darah & & & \\
Riwayat & Normal & 43 & 16,7 \\
penyakit & Tidak ada & 75 & 29,2 \\
Stroke & Ada & 182 & 70,8 \\
& SNH & 213 & 82,9 \\
& SH & 44 & 17,1 \\
\hline
\end{tabular}

Hasil analisis univariat yang terlihat pada table 1.1 menunjukkan bahwa lebih banyak responden dengan usia produktif $(65,4 \%)$, bekerja $(64,2 \%)$, menikah $(83,3 \%)$, kadar kolesterol total darah tidak normal $(83,3 \%)$, memiliki riwayat penyakit $(70,8 \%)$ dan jenis stroke terbanyak adalah stroke non hemoragik (SNH) 82,9\%.

Hasil analisis bivariate terlihat pada table 1.2 menunjukkan bahwa terdapat hubungan yang bermakna antara kadar kolesterol darah dengan kejadian stroke $(\mathrm{p}=0,005)$. Sedangkan hasil analisis multivariate yang tertuang pada table 1.3 menunjukkan bahwa factor penentu kejadian stroke $(\mathrm{OR}=0,047)$.

\subsection{Analisis Bivariat}

Table 1.2 Hubungan variabel independen dengan dependen

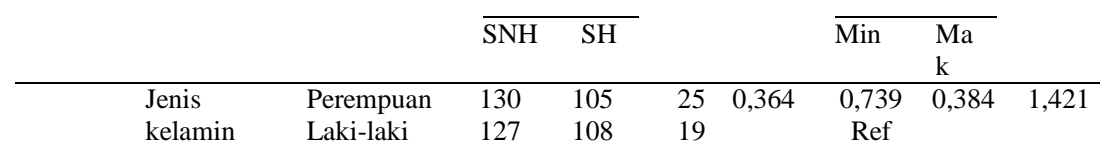




\begin{tabular}{|c|c|c|c|c|c|c|c|}
\hline Usia & $\begin{array}{l}\text { Tidak } \\
\text { produktif }\end{array}$ & 89 & 69 & 20 & 0.097 & 0,575 & 0,297 \\
\hline & Produktif & 168 & 144 & 24 & 0,187 & Ref & \\
\hline \multirow[t]{2}{*}{ Pendidikan } & $\begin{array}{l}\text { Pendidikan } \\
\text { rendah }\end{array}$ & 117 & 93 & 24 & 0,187 & 0,646 & 0,336 \\
\hline & $\begin{array}{l}\text { Pendidikan } \\
\text { tinggi }\end{array}$ & 140 & 120 & 20 & & Ref & \\
\hline \multirow[t]{2}{*}{ Pekerjaan } & $\begin{array}{l}\text { Tidak } \\
\text { Bekerja }\end{array}$ & 92 & 74 & 18 & 0,437 & 0,769 & 0,396 \\
\hline & Bekerja & 165 & 139 & 26 & & Ref & \\
\hline \multirow[t]{2}{*}{$\begin{array}{l}\text { Status } \\
\text { pernikahan }\end{array}$} & $\begin{array}{l}\text { Tidak } \\
\text { Menikah }\end{array}$ & 43 & 34 & 9 & 0,467 & 0,739 & 0,326 \\
\hline & Menikah & 214 & 179 & 35 & & Ref & \\
\hline Kadar & Tidak & 213 & 198 & 15 & 0,005 & 3,178 & 2,011 \\
\hline kolesterol & Normal & & & & & & \\
\hline darah & Normal & 44 & 13 & 31 & & Ref & \\
\hline Riwayat & Tidak Ada & 75 & 65 & 10 & 0,301 & 1,493 & 0,696 \\
\hline penyakit & Ada & 182 & 148 & 34 & & Ref & \\
\hline
\end{tabular}

1.3 Analisis Multivariate

Table 1.3 Hasil analisis multivariate regresi logistic

\begin{tabular}{|c|c|c|c|c|}
\hline & Variabel & Koefisien & $p$ & $\begin{array}{c}\text { OR } \\
(\text { IK95\%) }\end{array}$ \\
\hline \multirow[t]{4}{*}{ Langkah 1} & Usia & 0,976 & 0,022 & 2,654 \\
\hline & $\begin{array}{l}\text { Kadar } \\
\text { kolesterol } \\
\text { darah }\end{array}$ & $-3,087$ & 0,005 & 0,046 \\
\hline & $\begin{array}{l}\text { Riwayat } \\
\text { penyakit }\end{array}$ & $-0,623$ & 0,184 & 0,536 \\
\hline & Konstanta & $-0,062$ & 0,874 & 0,940 \\
\hline \multirow[t]{4}{*}{ Langkah 2} & Usia & 0,983 & 0,021 & 2,674 \\
\hline & $\begin{array}{l}\text { Kadar } \\
\text { Kolesterol } \\
\text { darah }\end{array}$ & $-3,097$ & 0,005 & 0,045 \\
\hline & $\begin{array}{l}\text { Riwayat } \\
\text { penyakit }\end{array}$ & $-0,637$ & 0,169 & 0,529 \\
\hline & Konstanta & $-0,014$ & 0,966 & 0,987 \\
\hline \multirow[t]{3}{*}{ Langkah 3} & Usia & 0,965 & 0,022 & 2,625 \\
\hline & Kolesterol & $-3,054$ & 0,005 & 0,047 \\
\hline & Konstanta & $-0,200$ & 0,483 & 0,818 \\
\hline
\end{tabular}

\section{Pembahasan}

Berdasarkan hasil penelitian ini, Hasil analisis univariat menunjukkan bahwa responden dengan usia produktif lebih banyak $(65,4 \%)$. Hal ini sejalan dengan penelitian yang sudah dilakukan oleh Raharjo, dkk (2015) di RSUD Kraton Kabupaten Pekalongan bahwa angka kejadian stroke terjadi pada usia produktif $(16,7 \%)$. Peningkatan usia menyebabkan terjadinya penurunan komplians pembuluh darah terhadap peningkatan tekanan aliran darah dan rentan terhadap cedera endotel. Berbeda dengan hasil dari data AIHW (2009) menunjukkan bahwa stroke mempengaruhi orang -orang dari segala umur dan kejadian stroke meningkat setiap pertambahan usia 10 tahun sejak usia 55 tahun keatas. Kabi, dkk (2013) menunjukkan bahwa stroke terjadi usia $<65$ tahun $(81,6 \%)$. Sejalan dengan penelitian yang dilakukan oleh Suiraoka (2014) bahwa stroke dialami oleh berbagai usia. Ghani, dkk (2016) menunjukkan bahwa proporsi responden terbanyak pada usia 35-44 tahun, disusul kelompok usia 15-24 tahun dan terlihat
,1Sfroke sudah muncul pada kelompok usia muda sebesar $0,3 \%$ dan proporsi meningkat tajam pada ,240ia 45 tahun ke atas. Hasil analisis bivariate menunjukkan bahwa terdapat hubungan antara usia dengan jenis stroke $(\mathrm{p}=0,097)$. Penelitian 1,49ain yang dilakukan oleh Ghani, dkk (2016) menunjukkan bahwa ada hubungan bermakna , 6 antara usia dengan kejadian stroke $(\mathrm{p}=0,0001)$. Begitu juga dengan penelitian yang dilakukan 5,02leh Sitorus, dkk (2006) menunjukkan bahwa faktor yang berpengaruh terhadap kejadian stroke pada usia muda dibawah 40 tahun dengan riwayat hipertensi, tekanan darah sistolik $\geq 140$ $\mathrm{mm} H g$ dan stroke pada keluarga. Beberapa penelitian yang lain yang dilakukan oleh Overbaugh (2009) menunjukkan bahwa laki-laki beresiko untuk terkena stroke pada usia $\geq 45$ tahun dan pada perempuan pada usia $\geq 55$ tahun. Kristiyawati, dkk (2008) dalam penelitiannya membuktikan bahwa terdapat hubungan yang signifikan antara usia dengan kejadian stroke $(\mathrm{p}=0,003)$. Hasil penelitian Raharjo, dkk (2015) menunjukkan bahwa ada hubungan yang bermakna antara faktor usia dengan jenis stroke pada pasien stroke di Poli Saraf RSUD Kraton Kabupaten Pekalongan dengan nilai $\mathrm{p}$ value 0,001 . Sedangkan hasil analisa multivariate menunjukkan bahwa usia sebagai salah satu factor yang berpengaruh terhadap jenis stroke di RSUD Provinsi Kepulauan Riau Tanjungpinang tahun 2017.

Hasil analisis univariat menunjukkan bahwa responden berjenis kelamin perempuan lebih banyak $(50,6 \%)$. Sejalan dengan penelitian yang dilakukan oleh Ghani, dkk (2016) menunjukkan bahwa proporsi responden dengan penyakit stroke terbanyak berjenis kelamin perempuan $(51,8 \%)$ dan berbeda dengan penelitian yang dilakukan oleh Kabi, dkk (2013) menunjukkan bahwa stroke terjadi pada laki-laki (55\%). Beberapa penelitian yang lain yang dilakukan oleh Overbaugh (2009) menunjukkan bahwa laki-laki beresiko untuk terkena stroke pada usia $\geq 45$ tahun dan pada perempuan pada usia $\geq 55$ tahun. Hasil analisis bivariat menunjukkan bahwa tidak terdapat hubungan antara jenis kelamin dengan jenis stroke $(\mathrm{p}=0,364)$.

Hasil analisis univariat menunjukkan bahwa responden dengan pendidikan tinggi (54,5\%) lebih banyak. Menurut Blum (1974) dalam Fadhila (2010) derajat kesehatan masyarakat merupakan hubungan dari empat faktor yaitu lingkungan, perilaku, keturunan dan pelayanan kesehatan. Perilaku dapat dalam tiga ranah antaralain kognitif, afektif dan psikomotor. Dalam perkembangan selanjutnya ketiga ranah 
tersebut diukur dari tingkat pengetahuan, sikap dan tindakan. Hasil analisis bivariate menunjukkan bahwa tidak terdapat hubungan yang bermakna antara pendidikan dengan kejadian stroke $(\mathrm{p}=0,187)$. Sejalan dengan penelitian yang dilakukan Fadhila dan Tugas woro (2010) menujukkan bahwa tidak ada hubungan antara pengetahuan, sikap dan perilaku tentang faktor risiko penyakit serebrovaskular terhadap kejadian stroke iskemik dengan nilai $\mathrm{p}>0,05$. Begitu juga dengan penelitian yang dilakukan oleh Pradita dan Rochmawati (2016) menunjukkan bahwa faktor demografi (jenis kelamin, kelompok umur, tingkat pendidikan, pekerjaan dan status pernikahan) tidak berhubungan dengan depresi pasien stroke dengan nilai $\mathrm{p}=0.502$.

Hasil analisis univariat menunjukkan bahwa responden dengan status bekerja lebih banyak $(64,2 \%)$. Sejalan dengan penelitian yang dilakukan oleh Ghani, dkk (2016) menunjukkan pasien stroke terbanyak adalah 59,6\% dengan status bekerja. Berbeda dengan data yang ditemukan oleh Kabi,dkk (2013) menunjukkan bahwa stroke iskemik terjadi pada orang yang tidak bekerja (30\%). Hasil analisis bivariate menunjukkan bahwa tidak terdapat hubungan antara pekerjaan dengan kejadian stroke $(\mathrm{p}=0,437)$. Hal ini sejalan dengan penelitian oleh Raharjo, dkk (2015) menunjukkan bahwa tidak ada hubungan antara faktor pekerjaan dengan jenis stroke pada pasien stroke di Poli Saraf RSUD Kraton Kabupaten Pekalongan dengan nilai $p$ value 0,988 . Begitu juga dengan penelitian yang dilakukan oleh Pradita dan Rochmawati (2016) menunjukkan bahwa faktor demografi (pekerjaan) tidak berhubungan dengan depresi pasien stroke dengan nilai $\mathrm{p}=0.134$.

Hasil analisis univariat menunjukkan bahwa status menikah $(83,3 \%)$ lebih tinggi. Hasil analisis bivariate menunjukkan bahwa tidak terdapat hubungan antara status pernikahan dengan kejadian stroke $(\mathrm{p}=0,647)$. Hal ini sejalan dengan penelitian yang dilakukan oleh Pradita dan Rochmawati (2016) menunjukkan bahwa faktor demografi (status pernikahan) tidak berhubungan dengan depresi pasien stroke dengan nilai $\mathrm{p}=0.445$.

Hasil analisis univariat menunjukkan bahwa responden lebih banyak memiliki kadar kolesterol darah normal (83,3\%). Hiperkolesterolemia merupakan keadaan ketika kadar kolesterol di dalam darah berlebih. Low density lipoprotein (LDL) $\geq 160 \mathrm{mg} / \mathrm{dl}, \mathrm{HDL} \geq$ $60 \mathrm{mg} / \mathrm{dl}$ atau trigliserida $\geq 150 \mathrm{mg} / \mathrm{dl}$ dan kolesterol darah total $\geq 240 \mathrm{mg} / \mathrm{dl}$ menyebabkan terbentuknya plak pada pembuluh darah yang lama kelamaan semakin banyak dan menumpuk sehingga menganggu aliran darah (Yusuf et al., 2004 dan Anderson, et al., 2013). Hasil analisis bivariate menunjukkan bahwa terdapat hubungan yang bermakna antara kadar kolesterol darah dengan kejadian stroke $(p=0,005)$. Hasil multivariate menunjukkan bahwa factor penentu kejadian stroke $(\mathrm{OR}=0,047)$.

Hasil analisis univariat menunjukkan bahwa lebih banyak dengan riwayat penyakit $(70,5 \%)$. Hasil analisis bivariate menunjukkan bahwa tidak terdapat hubungan antara riwayat penyakit dengan kejadian stroke $(\mathrm{p}=0,301)$. Berbeda dengan penelitian yang dilakukan oleh Ghani, dkk (2016) menunjukkan bahwa ada hubungan bermakna antara riwayat penyakit (hipertensi, DM, penyakit jantung coroner dan gagal jantung) dengan kejadian stroke $(\mathrm{p}=0,0001)$. Sitorus, dkk (2008) menunjukkan bahwa Faktor risiko yang secara bersama-sama berhubungan dengan kejadian stoke pada usia muda adalah ada riwayat hipertensi( $\mathrm{OR}=5,76$, $\mathrm{p}=0,001,95 \% \mathrm{CI}=2,09-15,94)$, riwayat keluarga ( $\mathrm{OR}=3,91, \mathrm{p}=0,06,95 \% \mathrm{CI}=1,89$ 20,49) dan tekanan darah sistolik $\quad(O R=0,26, p$ $=0,003,95 \% \mathrm{CI}=0,105-0,66)$. Terdapat 3 faktor risiko yang berpengaruh terhadap kejadian stroke pada usia muda di bawah 40 tahun yaitu riwayat hipertensi, tekanan darah sistolik $\geq 140$ dan riwayat stroke pada keluarga. Riwayat hipertensi, memberikan pengaruh yang bermakna untuk mengalami stroke pada usia muda dengan tingkat risiko 5,76 kali dibandingkan dengan yang tidak mempunyai riwayat hipertensi. Wicaksono, dkk (2013) dari analisis statistik diperoleh nilai $\mathrm{p}=0,037$ dan Odds Ratio $(\mathrm{OR})=$ 2,676 artinya bahwa rasio kadar kolesterol total terhadap HDL yang tinggi merupakan faktor risiko terhadap insidensi stroke iskemik.

\section{Kesimpulan dan Saran}

Faktor yang berpengaruh terhadap jenis stroke di RSUD Provinsi Kepulauan Riau Tanjungpinang tahun 2017 adalah usia dan kadar kolesterol darah. Peneliti selanjutnya sebaiknya meneliti semua variabel faktor risiko yang berhubungan dengan jenis stroke.

\section{Daftar Pustaka}

AHA/ASA Guidelines, 2014, Guidelines for the Prevention of Stroke in Patients With Stroke and Transient Ischemic Attack : A Guideline for Healthcare Professionals From the American Heart Association/American Stroke Association, Diakses melalui

http://stroke.ahajournals.org/content/strokeaha/early/2014/0 
4/30/STR.0000000000000024.full.pdf pada tanggal 17 Mei 2017.

AHA/ASA, 2015, Risk Factors for Stroke, Diakses melalui https://www.strokeassociation.org/.../stroke.../ucm 309713. pdf. Pada tanggal 20 april 2015

American Heart Association Statistics Committee and Stroke Statistics Subcommittee. Heart disease and stroke statistics-2016 update: a report from the American Heart Association. Circulation, 2016;133:e38-e360, Diakses melalui https://www.heart.org/idc/groups/ahamahpublic/@wcm/@sop/@smd/documents/downloadable/ucm 480110.pdf

Australian Institute of Health and Welfare (AIHW), 2009, National hospital morbidity data, http://d01.aihw.gov.au/cognos/cgi-

bin/ppdscgi.exe?DC=Q\&E=/ahs/pdx0607, di akses 20 Februari 2014.

Bull, F.,C., Armstrong, T.,P., Dixon, T., Ham, S., Neiman, A and Pratt, M., ,2004, Comparative quantification of health risks: Global and regional burden of disease attributable to selected major risk factors, World Health Organization, Geneva 1, Diakses pada tanggal 17 Mei 2017, melalui apps.who.int/iris/bitstream/10665/42792/1/9241580348_en g_Volume1.pdf

Heart Foundation, 2009, Heart disease risk factors, http://www.heartfoundation.org.au/Heart Information/Risk _Factors/Pages/default.asp x, accessed on 16 Maret 2014.

Irfan, M., 2011, Fisioterapi Bagi Insan Stroke, Graha Ilmu, Jakarta.

Irma, O.,W dan Santi, M., 2015, HUBUNGAN ANTARA KARAKTERISTIK PASIEN STROKE DAN DUKUNGAN KELUARGA DENGAN KEPATUHAN MENJALANI REHABILITASI. Jurnal Berkala Epidemiologi 3 (1): 24-34

McPhee, S.,J dan Ganong, W.,F ,2010, Patofisiologi Penyakit : menuju kedokteran klinis Ed 5, EGC, Jakarta.

Muttaqin, A., 2008, Asuhan Keperawatan Klien dengan Gangguan Sistem Persarafan, Salemba Medika, Jakarta.

Noor, N.,N ,2008, Epidemologi, Rineka Cipta, Jakarta

National heart, lung and blood institute (NHLBI), 2001, diakses melalui https://www.nhlbi.nih.gov/health/healthtopics/topics/stroke/signs\# tanggal 5 MEI 2017

Overbaugh, K., J ,2009, Acute coronary syndrome : even nurses outside the ED should recognize its sign and symtomps, AJN 109(5):42-52.

RISKESDAS, 2013, Diakses melalui http://www.depkes.go.id/resources/download/general/Hasil \%20Riskesdas\%202013.pdf. Pada tanggal 24 Februari 2017

Ratna, D., 2011, Penyakit Pemicu Stroke, Nuha Medika,Yogyakarta.

Smeltzer, S , C., \& Bare, B.G., 2005, Buku Ajar Keperawatan Medical Bedah Brunner \&. Suddart Edisi 8, Vol 1, Philadelphia, Lippincott.
Sitorus, R.J., Hadisaputro, S dan Kustiowati, E, 2008. Faktor-faktor yang mempengaruhi kejadian stroke pada usia muda kurang dari 40 tahun, Diakses melalui eprints.undip.ac.id/6482/ pada tanggal 24 April 2017.

Suiraoka, 2012, Penyakit degenerative, Nuha Medika. Yogyakarta.

Tarwoto, 2013, Keperawatan Medikal Bedah Gangguan Sistem Persarafan, Sagung Seto, Jakarta.

Udjianti, W,U., 2010, Keperawatan Kardiovaskular.Salemba Medika, Jakarta.

Vos, T., and Begg, S., 2007, The burden of cardiovascular disease in Australia for the year 2003, National Heart Foundation of Australia, http://www.heartfoundation.org.au/Heart_Information/Stati $\underline{\text { stics/Pages/default.asx }}$, accessed 16 Maret 2014.

Wartonah, dkk., 2007, Keperawatan Medikal Bedah Gangguan Sistem Persarafan. Sagung Seto, Jakarta.

World Health Organization (WHO). 2008. The global burden of disease : 2004 update. Diakses melalui www.who.int/evidence/bod pada tanggal 25 April 2017.

Yusuf, S., Hawken, S., Ounpuu, S., Dans, T., Avezum, A., Lanas, F., McQueen, M., Budaj, A., Pais, P., Varigos, J and Lisheng, L. 2004. Effect of potentially modifiable risk factors associated with myocardial infarction in 52 countires (the INTERHEART study): case control study, The Lancet 364:937-95

Yvonne,T., dan CHRISTENSEN, M., 2012.The pathophysiology of ischaemic stroke: Considerations for Emergency Department Advanced Practice Nursing. Volume 39(2): 31-39. 